\title{
ホモシステイン関連酵素（血栓症の関 連から)
}

山田和弘 ${ }^{*}$

Homocysteine metabolism and related enzymes

Kazuhiro YAMADA*

Key words: methionine-folate metabolism, hyperhomocysteinemia, methylenetetrahydrofolate reductase, methionine synthase

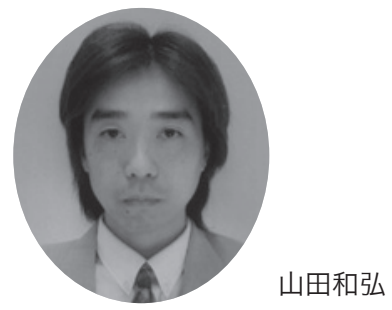

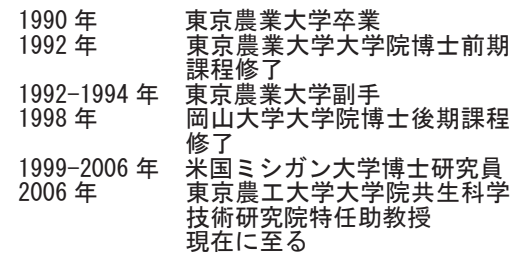

\section{はじめに}

ホモシステインはメチオニンの代謝物であ る。近年, 血中ホモシステイン濃度の上昇（高 ホモシステイン血症）は心疾患 ${ }^{1)}$ や神経管欠 損 ${ }^{2)}$ に対して独立した危険因子であることが明 らかになり，この代謝に関わる酵素の性質につ いて再び関心が高まっている。メチオニン・葉 酸代謝（図 1) は，核酸の生合成，タンパク質 合成，ポリアミンの合成およびトランスメチレ ーションに関与する重要な代謝であるので, 古 くからアミノ酸と水溶性ビタミンの機能に関 して研究が行われてきた。図 1 に示したよう に，ホモシステイン代謝に係わる酵素はメチオ ニン合成酵素 $(\mathrm{MS})$, シスタチオニン $\beta$ シンタ 一ゼ (CBS), ベタインホモシステインメチル トランスフェラーゼ (BHMT), アデノシルホ モシステイン加水分解酵素 (SAHase), メチレ ンテトラヒドロ葉酸還元酵素（MTHFR）であ る。この代謝で重要は点はこれらの代謝酵素活 性の制御である。今回取り上げるこれらの酵素 は全て補因子（補酵素や金属原子）を活性発現 に必要としている. 従って, メチオニン・葉酸
代謝は栄養素摂取（すなわち，アミノ酸，ビ夕 ミンやミネラルの供給）の影響を強く受けるこ とが知られている。一方，ヒト個人間の遺伝子 の違い（遺伝子多型）は，タンパク質の性質を 変化させ, 病気の罹り易さに影響すると考えら れる、本総説ではメチオニン・葉酸代謝につい て概説し，ホモシステイン代謝酵素として特に MTHFR と MS について最近の生化学的知見を 紹介する.

\section{メチオニン・葉酸代謝}

葉酸は生体内でメチル基 $\left(\mathrm{CH}_{3}-\right)$ やホルミ ル基 (CHO-) などいわゆる $\mathrm{C} 1$ ユニット（一 炭素化合物）の運び屋として機能する大切な ビタミンである（図 1)。葉酸代謝の重要性は $\mathrm{DNA} \cdot \mathrm{RNA}$ 前駆体の生合成にある。C1 ユニッ トはプリン塩基の生合成に使用される。また， チミジル酸合成酵素の作用によってチミジル酸 (dTMP) の生合成にも利用される.

一方で葉酸 $\mathrm{C} 1$ ユニットはメチオニン合成に 用いられる、高等動物においてメチオニンは必 須アミノ酸であるが，ホモシステインを再メチ

*東京農工大学大学院共生科学技術研究院〔＝ 184-8588 東京都小金井市中町 2-24-16〕

The Institute of Symbiotic Science and Technology, Tokyo University of Agriculture and Technology [2-24-16 Nakacho, Koganei, Tokyo 184-8588]

Tel: 042-388-7479 Fax: 042-388-7479 e-mail: yamadak@cc.tuat.ac.jp 


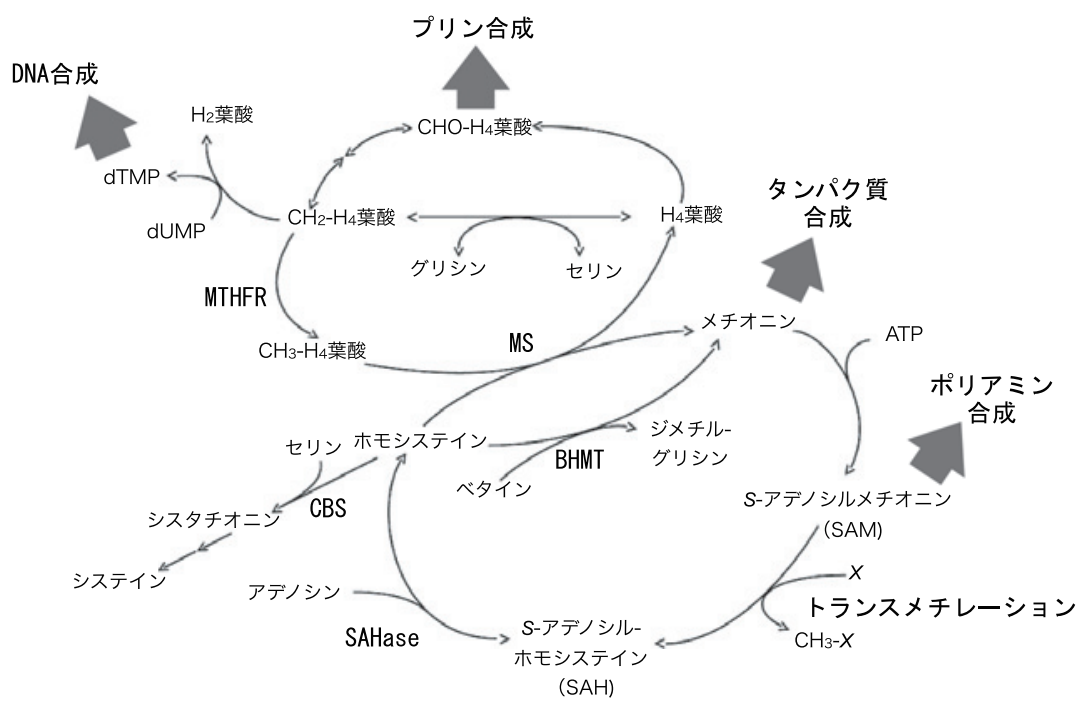

図 1 メチオニン・葉酸代謝

ル化することで合成することが出来る.メチオ ニンは体タンパク質の生合成に必要であるばか りではなく, ATP と化合しアデノシルメチオ ニン（SAM）となる. SAM はポリアミンの基 質であるのみならず，多くのメチル化反応の基 質となる。メチル基を供与した SAM はアデノ シルホモシステイン（SAH）となった後, アデ ノシンとホモシステインに加水分解される。ホ モシステインはMSにより再メチル化されてメ チオニンになるか，または CBS の触媒反応に よりセリンと化合しシスタチオニンとなった 後, システインへと異化される。このようにメ チオニン・葉酸代謝は多くの経路とリンクして おり，生体にとって重要な代謝である.

\section{アデノシルメチオニンと代謝制御}

メチオニン・葉酸代謝には重要な分岐点が 2 カ所ある。一つはホモシステインを再メチル化 に利用するか，またはシステインに異化代謝 するかの分岐.もう一つは，メチレンテトラヒ ドロ葉酸の C 1 ユニットをデオキシウリジル酸 (dUMP) へと渡しdTMP 合成の使用するか, またはメチルテトラヒドロ葉酸に還元した後,
メチオニン合成に利用するかの分岐である.

ホモシステインの再メチル化と異化代謝の分 岐では，CBS 活性の調節が行われる，SAM は CBS の活性化剂であり, 高濃度の SAM により CBS の活性は上昇する ${ }^{3)}$ 。この調節は細胞内の メチオニン濃度が高い時にメチオニンを異化代 謝を促進する応答であると考えることが出来 る.

一方，メチレンテトラヒドロ葉酸の $\mathrm{C} 1$ ユニ ットを核酸合成かメチオニン合成に使用するか はMTHFR 活性を制御することによって行う。 SAM は MTHFR の強力なアロステリック阻害 剂である4). SAH は MTHFR を活性化しないが, SAM と MTHFR の結合を阻害する。すなわち $\mathrm{SAM}$ / SAH の比率によって MTHFR の活性は 調節されている.

この SAM / SAH 比は SAM 依存性メチル基転 移酵素にとっても重要な比率である ${ }^{5)}$. SAH は 多くの SAM 依存性メチル基転移酵素の競合阻 害剂である。従って, 細胞内 SAH 濃度の上昇 は，SAM 依存性メチル基転移酵素活性を低下 させ，メチル化化合物を減少させる ${ }^{5)}$.このよ うにSAM はメチオニン・葉酸代謝に関係する 酵素の活性制御に中心的な役割を果たしている. 


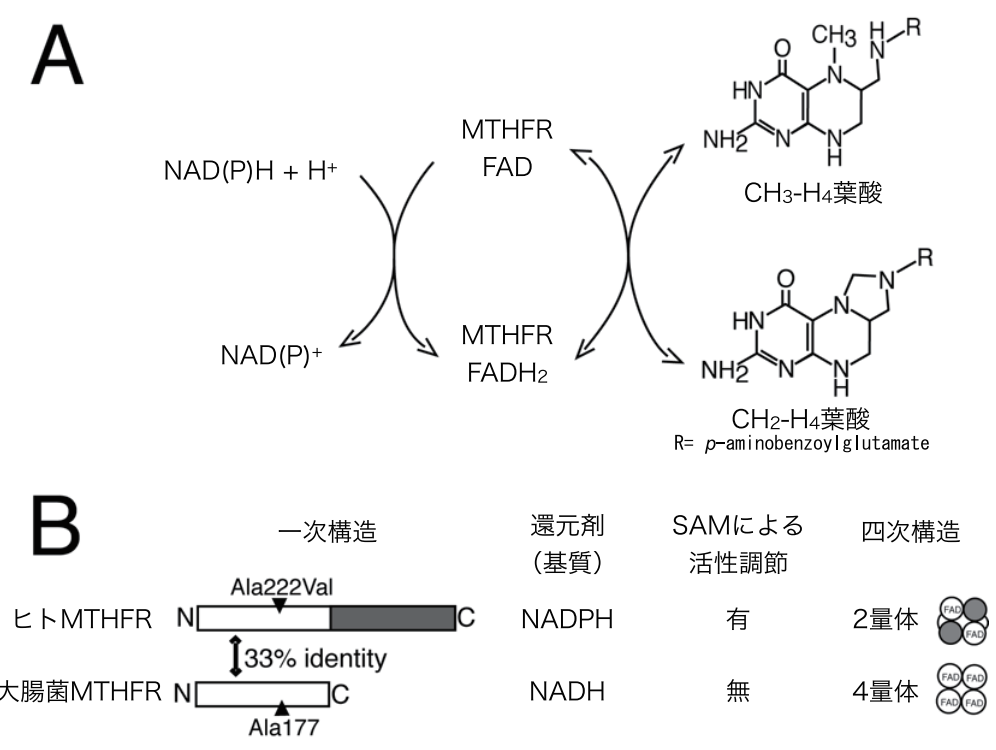

図 2 MTHFR の触媒する反応（A）およびヒト酵素と大腸菌酵素との比較（B）

\section{高ホモシステイン血症と MTHFR 遺伝子变異}

血中ホモシステイン濃度と動脈硬化のリス クについて 1969 年に McCully が報告してい

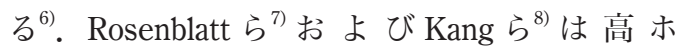
モシステイン血症患者と MTHFRの熱耐性に ついて検討，患者の中で高温（46 度）で失 活しやすい酵素を持つグループを発見した。 1995 年に Rozen らのグループによってヒト MTHFRcDNA の全長がクローニングされ ${ }^{9) ， ヒ ~}$ 卜 MTHFR 遺伝子の $677 \mathrm{C}>\mathrm{T}$ 遺伝子多型が報 告された。この遺伝子変異は 222 番目のアミ ノ酸をアラニンからバリンに変化させるもの （Ala222Val）である。（注；MTHFRの遺伝子 クローニングの時に翻訳開始点が決められな かったために，この MTHFR 変異の核酸の番 号とタンパク質のアミノ酸番号にはズレがあ る. ) 677C > T 変異は common polymorphism で あり，ホモ接合性は約 $10 \%$ 程度である ${ }^{10)}$. 日 本人においても同様の割合であると報告され ている ${ }^{11)}$.677C>T ホモ接合体患者の MTHFR 活性は低く，血中ホモシステイン濃度高めで ある ${ }^{12)}$. Ala222 Val 変異体酵素は熱安定性が悪
いことが示され9)，先に報告された熱感受性 MTHFR と遺伝子変異の因果関係が明らかとな った。

\section{メチレンテトラヒドロ葉酸還元酵素 (MTHFR)}

MTHFR が触媒するのはメチレンテトラヒド ロ葉酸を還元しメチルテトラヒドロ葉酸を生 成する反応である ${ }^{13)}$. MTHFR は酵素反応に必 須なフラビンアデニンジヌクレオチド（FAD） と非共有結合している(図 2)。ヒト MTHFR は NADPH を基質とし，メチレンテトラヒドロ葉 酸を還元し, メチルテトラヒドロ葉酸を生成す る. 従って MTHFR は直接ホモシステインを 基質とする酵素ではない。しかし，生成物のメ チルテトラヒドロ葉酸はメチオニン合成反応の 基質であるので，MTHFR は基質の供給という 点で間接的に関与し，ホモシステイン量の調節 に中心的な役割を果たしている。

ヒトMTHFRはホモ 2 量体で， $\mathrm{N}$ 末端の触 媒領域と C 未端の調節領域に分けることが出 来る（図 2)。高等動物 MTHFR の立体構造は 


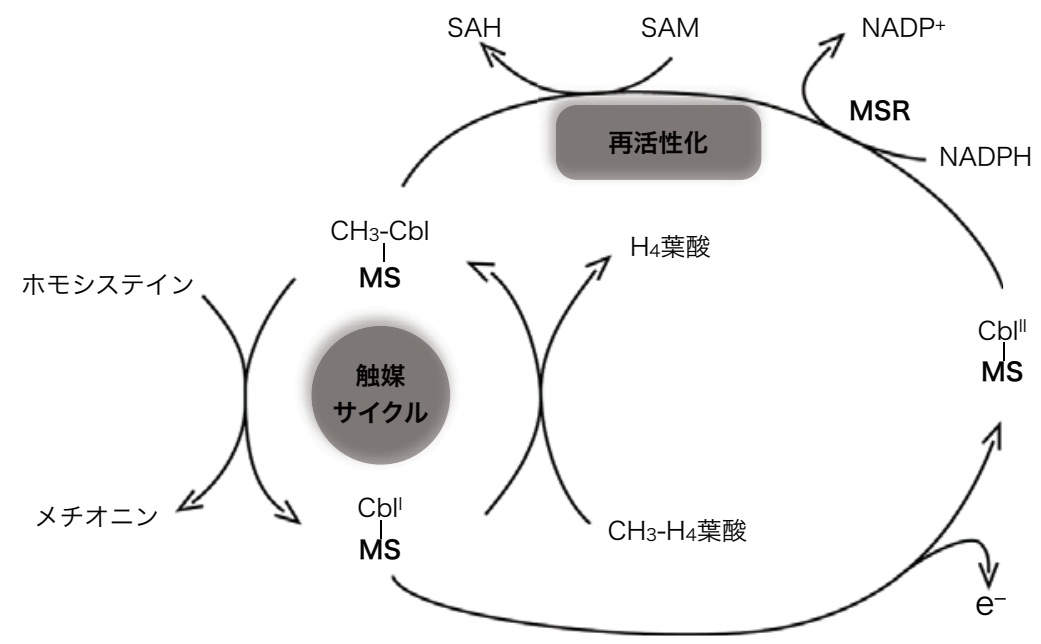

図 3 メチオニン合成酵素（MS）が触媒する反応とメチオニン合成酵素還元酵素に よる再活性化

未だに明らかになっていない. 大腸菌 MTHFR は調節領域を持たないので SAM による活性調 節を受けないが，ヒトMTHFRの触媒領域は 大腸菌 MTHFR と高い相同性（33\%の同一性） を示すことから，立体構造は類似していると考 えられる。1999 年に Ludwig らのグループによ り, 大腸菌 MTHFRの結晶構造解析が報告さ れた ${ }^{14)}$. 大腸菌酵素は $\alpha 8 \beta 8$ バレル構造のサブ ユニットの 4 量体であり，活性中心に $\mathrm{FAD}$ が 結合している。 ヒト MTHFR・Ala222 は大腸菌 酵素 Ala177 に相当するが，大腸菌 MTHFR の タンパク質立体構造ではこのアラニン残基は触 媒中心から離れたところに位置していた。すな わち Ala222Val 変異は酵素活性に直接影響しな いことが示唆された。大腸菌 MTHFR ${ }^{\text {Ala177Val 変 }}$ 異体を用いて，このアミノ酸置換が酵素機能に 与える影響が調べられた ${ }^{14)}$. 変異体大腸菌酵素 の酵素活性は野生型と変わらないことが観察さ れたが，変異体酵素を希釈すると野生型よりも 約 10 倍速く補酵素 FAD を失うことが観察され た。変異体酵素では立体構造が不安定であるた めに補酵素を失い，失活すると推測された。最 近明らかにされた大腸菌 MTHFR ${ }^{\text {Ala177Val 変異体 }}$ の立体構造はこの仮説を支持している ${ }^{15)}$ 。しか
し，ヒトMTHFR サブュニットが約 $70 \mathrm{kDa} の$ 2 量体であり, 大腸菌酵素とは異なっている. 著者らは組み換え体ヒトMTHFRの性質を調 べた ${ }^{16)}$.その結果, 野生型と変異体では酵素活 性など酵素機能に差は観察されなかったが，変 異体酵素は FAD を野生型よりも約 3 倍速く失 うことを観察した。また，葉酸が MTHFRの 活性失活を防ぐという実験的根拠を示した。葉 酸の投与が血中ホモシステイン濃度低下に有効 である理由の一つであると考えている。

最近，著者らはヒトMTHFRがリン酸化に より制御されていることを明らかにした。この リン酸化は酵素活性の調節, 特に SAM による アロステリック調節に重要である ${ }^{17)}$.

\section{メチオニン合成酵素（MS）とメチオニン 合成酵素還元酵素（MSR）}

MS はメチルテトラヒドロ葉酸のメチル基を ホモシステインへわたし，テトラヒドロ葉酸と メチオニンを生成する反応を触媒する（図 3). $\mathrm{MS}$ は亜鉛とビタミン $\mathrm{B}_{12}$ （コバラミン, $\mathrm{Cbl}$ （図 3））を補因子として結合している。コバラ ミンはメチル基転移反応において中心的な役 
割を果たす。高等動物 MS のホモシステインに 対する親和性は非常に高く, $K m$ 值は約 $2 \mu \mathrm{M}$ である ${ }^{18)}$ ので，MS は生理量のホモシステイン （血中濃度約 $10 \mu \mathrm{M} ）$ を効率よく代謝すること ができると考えられる。

コバラミンは酵素反応途中で酸化され易く, MS は 1,000 2,000 回の触媒に 1 回の割合で不 活性化する ${ }^{19)}$. 高等動物の場合，不活性化 MS を再活性化する酵素がメチオニン合成酵素還元 酵素（MSR）である。コバラミンは，MSR と NADPHにより還元され，SAM からメチル基 を受け取ることで再活性化される，MSR は補 酵素として FMN と FAD を結合する，P450 還 元酵素ファミリーに属する酵素である，MSR は遺伝学的な研究から存在が示唆されていた が，最近まで生化学的な性格が不明なタンパ ク質であった。 1998 年に Gravel らのグルー プがヒト MSRcDNA クローニングに成功し ${ }^{20)}$, Banerjee らのグループにより初めて MSR 依存 的 MS 酵素活性が報告されている21).

\section{その他のホモシステイン代謝酵素}

CBS はビタミン $\mathrm{B}_{6}$ 依存性酵素であり，ホモ システインとセリンからシスタチオニンを生 成する反応を触媒する酵素である。 CBSのホ モシステインに対する基質親和性は低い。しか し高等動物において CBS はホモシステインか らシステインを生成する反応を触媒する唯一の 酵素であるので, CBS 遺伝子の欠損は極度の 高ホモシステイン血症を引き起こす ${ }^{22)}$. 最近, SAM は CBS タンパク質を安定化することが明 らかになった ${ }^{23)}$.すなわち，大量にメチオニン を摂取した場合，CBS はSAM により安定化さ れ，さらに活性化されると考えられる。

SAHase はSAHを加水分解し, アデノシ ンとホモシステインを生成する反応を触媒す る。この反応は可逆反応である ${ }^{24)}$. アデノシン やホモシステインが高濃度に存在すると, 平 衡はSAH を合成する方向に偏る。すなわち,
細胞内のホモシステインやアデノシン濃度は $\mathrm{SAM} / \mathrm{SAH}$ 比を調節する因子の一つであると 考えられる。

BHMT はベタイン（トリメチルグリシン） のメチル基をホモシステインへと渡し，メチオ ニンを合成する反応を触媒する酵素である。特 に肝臓で酵素活性が高く検出されるが，他の蔵 器中の本酵素活性は非常に低い ${ }^{25)}$ 。また，べ夕 インのメチル基は SAM に由来するので，正味 のメチオニン合成（ホモシステイン代謝）が行 われるわけではない。しかし，Mthfr 遺伝子欠 損マウス ${ }^{26)}$ やヒト ${ }^{27)}$ にベタインを投与するこ とでホモシステイン代謝が改善されることが報 告されている.

\section{おわりに}

今回，ホモシステイン代謝に関与する酵素に ついて生化学的な性質を紹介した。ホモシステ イン代謝に関連する報告は多くあるが，「なぜ 高ホモシステイン血症が心疾患の危険因子なの か」という疑問に今のところ答えはない。血栓 症の発症機序としては，血管内皮細胞の障害， 血小板の活性化，凝固機能の立進などが考えら れている。しかしこれらに対してホモシステイ ンが直接毒性を発揮するのか, または血中ホモ システインは単なるマーカーであり直接の毒素 ではないのかということも明らかにはなってい ない。

高ホモシステイン血症患者への葉酸投与は 血中のホモシステイン濃度低下に有効である. 1996 年にアメリカでは FDA（食品医薬局）が 高栄養価穀物食品に葉酸を強化することを求 $\bigotimes^{28)} ， 1998$ 年から義務づけている。 日本では 食生活の違いから葉酸が欠乏することは少ない とされているが，今後，食生活の欧米化により 葉酸の摂取が減少し，高ホモシステイン血症患 者が増加する可能性も考えられる。 


\section{文献}

1) Graham IM, Daly LE, Refsum HM, Robinson K, Brattstrom LE, Ueland PM, Palma-Reis RJ, Boers GH, Sheahan RG, Israelsson B, Uiterwaal CS, Meleady R, McMaster D, Verhoef P, Witteman J, Rubba P, Bellet H, Wautrecht JC, de Valk HW, Sales Luis AC, Parrot-Rouland FM, Tan KS, Higgins I, Garcon D, Andria G, et al: Plasma homocysteine as a risk factor for vascular disease. The European Concerted Action Project. J Am Med Assoc 277 : 1775-1781, 1997.

2) van der Put NM, Steegers-Theunissen RP, Frosst P, Trijbels FJ, Eskes TK, van den Heuvel LP, Mariman EC, den Heyer M, Rozen R, Blom HJ: Mutated methylenetetrahydrofola te reductase as a risk factor for spina bifida. Lancet $\mathbf{3 4 6}$ : 1070-1071. 1995

3) Finkelstein JD, Kyle WE, Martin JL, Pick AM: Activation of cystathionine synthase by adenosylmethionine and adenosylethionine. Biochem Biophys Res Commun 66 : 81-87, 1975.

4) Kutzbach C, Stokstad EL: Mammalian methylenetetrah ydrofolate reductase. Partial purification, properties, and inhibition by S-adenosylmethionine. Biochim Biophys Acta 250 : 459-477, 1971.

5) Hoffman DR, Cornatzer WE, Duerre JA: Relationship between tissue levels of S-adenosylmethionine, S-adenylhomocysteine, and transmethylation reactions. Can J Biochem 57 : 56-65, 1979.

6) McCully KS: Vascular pathology of homocysteinemia: implications for the pathogenesis of arteriosclerosis. Am J Pathol 56 :111-128, 1969.

7) Rosenblatt DS, Erbe RW: Methylenetetrahydrofolat e reductase in cultured human cells. II. Genetic and biochemical studies of methylenetetrahydrofolate reductase deficiency. Pediatr Res 11 : 1141-1143, 1977

8) Kang SS, Passen EL, Ruggie N, Wong PW, Sora H: Thermolabile defect of methylenetetrahydrofolate reductase in coronary artery disease. Circulation $88: 1463-1469$, 1993.

9) Frosst P, Blom HJ, Milos R, Goyette P, Sheppard CA, Matthews RG, Boers GJ, den Heijer M, Kluijtmans LA, van den Heuvel LP, et al: A candidate genetic risk factor for vascular disease: a common mutation in methylenetetrahydr ofolate reductase. Nat Genet 10 : 111-113, 1995.

10) Weisberg I, Tran P, Christensen B, Sibani S, Rozen R: A second genetic polymorphism in methylenetetrahydrofolat e reductase (MTHFR) associated with decreased enzyme activity. Mol Genet Metab 64 : 169-172, 1998.

11) Nishio H, Lee MJ, Fujii M, Kario K, Kayaba K, Shimada K, Matsuo M, Sumino K: A common mutation in methylenetetr ahydrofolate reductase gene among the Japanese population. Jpn J Hum Genet 41 : 247-251, 1996

12) Ueland PM, Hustad S, Schneede J, Refsum H, Vollset SE: Biological and clinical implications of the MTHFR C677T polymorphism. Trends Pharmacol Sci 22 : 195-201, 2001

13) Matthews RG: Methylenetetrahydrofolate reductase from pig liver. Methods Enzymol 122 : 372-381, 1986.

14) Guenther BD, Sheppard CA, Tran P, Rozen R, Matthews RG, Ludwig ML: The structure and properties of methyle netetrahydrofolate reductase from Escherichia coli suggest how folate ameliorates human hyperhomocysteinemia. Nat Struct Biol 6 : 359-365, 1999
15) Pejchal R, Campbell E, Guenther BD, Lennon BW, Matthews RG, Ludwig ML: Structural perturbations in the Ala -> Val polymorphism of methylenetetrahydrofol ate reductase: how binding of folates may protect against inactivation. Biochemistry 45 : 4808-4818, 2006.

16) Yamada K, Chen $Z$, Rozen R, Mattwhes RG : Effect of common polymorphisms on the properties of recombinant human methylenetetrahydrofolate reductase. Proc Natl Acad Sci U S A 98 : 14853-14858, 2001.

17) Yamada K, Strahler JR, Andrews PC, Matthews RG: Regulation of human methylenetetrahydrofolate reductase by phosphorylation. Proc Natl Acad Sci U S A 102 : 10454-10459, 2005.

18) Yamada K, Tobimatsu T, Kawata T, Wada M, Maekawa A, Toraya T: Purification and some properties of cobalamindependent methionine synthase from rat liver. J Nutr Sci Vitaminol (Tokyo) $43:$ 177-186, 1997.

19) Yamada K, Yamada $S$, Tobimatsu T, Toraya T: Heterologous high level expression, purification, and enzymological properties of recombinant rat cobalamin-dependent methionine synthase. J Biol Chem 274 : 35571-35576, 1999.

20) Leclerc D, Wilson A, Dumas R, Gafuik C, Song D, Watkins D, Heng HH, Rommens JM, Scherer SW, Rosenblatt DS, Gravel RA: Cloning and mapping of a cDNA for methionine synthase reductase, a flavoprotein defective in patients with homocystinuria. Proc Natl Acad Sci U S A 95 : 3059-3064, 1998.

21) Olteanu H, Banerjee R: Human methionine synthase reductase, a soluble $\mathrm{P}-450$ reductase-like dual flavoprotein, is sufficient for NADPH-dependent methionine synthase activation. J Biol Chem 276 : 35558-35563, 2001.

22) Watanabe M, Osada J, Aratani Y, Kluckman K, Reddick R, Malinow MR, Maeda N: Mice deficient in cystathionine beta-synthase: animal models for mild and severe homocyst (e) inemia. Proc Natl Acad Sci U S A 92 : 1585-1589, 1995.

23) Prudova A, Bauman Z, Braun A, Vitvitsky V, Lu SC, Banerjee R: S-adenosylmethionine stabilizes cystathionine beta-synthase and modulates redox capacity. Proc Natl Acad Sci U S A 103 : 6489-6494, 2006.

24) G. de la Haba, G. L. Cantoni : The Enzymatic Synthesis of S-Adenosyl-1-homocysteine from Adenosine and Homocysteine. J. Biol. Chem 234 : 603-608, 1959.

25) Sunden SL, Renduchintala MS, Park EI, Miklasz SD, Garrow TA: Betaine-homocysteine methyltransferase expression in porcine and human tissues and chromosomal localization of the human gene. Arch Biochem Biophys 345 : 171-174, 1997.

26) Schwahn BC, Laryea MD, Chen Z, Melnyk S, Pogribny I, Garrow T, James SJ, Rozen R: Betaine rescue of an animal model with methylenetetrahydrofolate reductase deficiency. Biochem J 382 (Pt 3) : 831-840, 2004.

27) Kishi T, Kawamura I, Harada Y, Eguchi T, Sakura N, Ueda K, Narisawa K, Rosenblatt DS: Effect of betaine on $\mathrm{S}$-adenosylmethionine levels in the cerebrospinal fluid in a patient with methylenetetrahydrofolate reductase deficiency and peripheral neuropathy. J Inherit Metab Dis 17 : 560-565, 1994.

28) Food and Drug Administration (FDA). Food Standards: Amendment of Standards of Identity for Enriched Grain Products to Require Addition of Folic Acid; Final Rule (21 CFR Parts 136, 137, and 139). Federal Register 61 : 8781-8797, 1996. 